\title{
船員通信教育(高等科)についての若干の調查
}

\section{Survey on the Seaman's Correspondece Instruction (Officer's Course)}

\section{柴 田 武 雄 (海技專門学院) \\ 浦 田 楠 雄 (海技專門学院)}

\begin{abstract}
The Correspondence Course for Ship Officers was established in Kaigi-Semmon Gakuin in 1951, and its aim is to give knowledge and technical skill necessary for deck and engineering officers.

In this paper, we shall report the result of our recent survey on the actual condititions and opinions of the correspondence-students.

According to the survey, generally ship officers under 35 years old the main source of the students, and they consist of the graduates of all seafarers' educational institutions in Japan and others.

Such content as useful to fulfil their duties successfully is supported as the aim of compiling text-books, Such instructive activities as question \& answers, reports and schooling are to be taken up more positively. On the educational management, the speciality of ocean-going ship service is to be fully considered.

In conclusion, it is important to realize "a correspondence instruction of the ship officers, by the ship officers, for the ship officers".

\section{1 まえがき}

船船の属員に対する普通科通信教育に対して、船船職員を対象とするものが高等科の通信教育 である。このたび高等科通信生の実態と意見につんて若干の調査をしたので、その要点を紹介す
\end{abstract} る。

\section{2 高等科通信生の実態}

この調査は入学願書等の書類を基礎にした。

(1) 附区 1〜4による上、高等科通信教育の対象として、最終学歴は商船学校（商船高校）現 職は二航〜三航、二機〜三機、乗航履歴は 5 年程度、所有免状は甲一〜甲二の者を一応の基準と してよんととが判明する。

（2）附図 5 〜 8 亿よる、乗船年数11年委での者が通信生の主要ソースで、年令では一航一機 の平均年命玉でが一つの山を形成しており、二航〜三航、二機〜三機の平均年命間がその中核と 
なつている。年令曲線の山の中味を適確につかむととが、との教育の内容方法を検討する土台とな る。学歷別に考えると、戦後本学院本科学生の有力なンースであつを專科刃は短期出身者は、す でにこの山の下り坂に占位し、戦後派がその山頂を占有しつつある事実に注目すべきであるら。 最年長者は航海科 65 才、機関科 57 才となつている。(注) 附図 7,8 の職別平均年令は海運統計年報 31 年 版による6000総电以上の乗組の平均年令である。

(3) 35才以下の通信生で甲長免状所有者亡甲一以下の免状所有者との割合を示したものが、附 図 9 である。乙れによると35才以下の通信生は総数の $80 \%$ 内外であり、甲長所有者は逐年疗痤 2

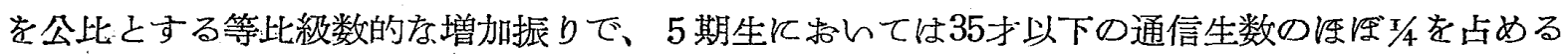
に至つている。てれらの最高免状所有者は現場における職務遂行に必要な知識技能を得るために のみ大学するである.5L、一方甲一以下のものは海技試験準備のをめにも通信教育を利用してん るであろら。こてで我ふは現場の船舶士官の技術振興をはかる通信教育が両者の公約数であり、 本教育本来の狙んであるとと再確認しなければならなん。

（4）35于以下の通信生中、甲長所有者の所属先别人数を当つてみをとてろ、附図10の通り、学 資補助をしてんるXY二社所属者数が過去 3 力年飞和て鳘異的な増加を示し、 5 期生におんて は約半数を占め甲長所有者増加の主体となつてんる。通信生を動機付ける最有力のるのは何とん つても最高免状を得て安定したんとんら願望であるらと思われるが、使用者側の僅かを配虑が甲 長免状所有者に対して、てれ程をでに勉学意欲を起させている。

(5) つぎに甲機職員 80 名以上を有する任意の10社の、5期生入学者/甲機職員合計(\%)を示し たものが附図11である。学院亡本教育に関して特に密接な連けんを保つている約90社の甲機職員 合計は約10,000名であるから普及率が10\%となれば、と礼らの船会社のみで募集定員を满たし る。「高等科の教育效果をあげるために本学院として、ぞんなととをしをらよんか」の問いに対 し、一部の通信生は「学院は教育效果につんて慣题する必要はない。我及は船の現場で高等科通 信生である者之他の者との間に格段の差がつきつつあるてとを自覚している」と答えている。と の意見が普辺的であるとするならば、普及率 $50 \%$ A 社と $1.2 \%$ I 社との将来に持ける懸隔を 推定しらるであろら。

（6）附図12は各期別通信生数の変化が示されている。機関科の踓進にくらべて航海科が伸びな やんでんるのが注目される。

\section{3 高等科通信生の意見}

調查期間、昭和31.6 31. 10，質問紙発送数680，回收数214（内訳 N70，E144), 回収率31.4\% (1) 希望教科書テーマ(数字は件数)

航海科、運用 (32)……保安応急法 ( 9 ), 荒天航泊法 ( 8), 船舶整備 ( 5 ), 一般操船( 4 ), 船舶 工学船用機関(4), 空船航海(2), 計器 (30)……取扱調整と故障対策(10), 新式ジヤイロ及びジヤ イロ・パイロツト(9), 基礎知識(7)，新計器(4)，海運(28)……運航採算(4)，海運実務(4)，海上保険 (4), 共同海損(4), 傭航契約書(4), 船荷証券(4), 海:運情勢(3), 海商法(1), 航海(26)…..誤差論(8), 航 法(7), 航路選定(6), 気象海象(5), 載貨(22)……取扱積付管理(11), 載貨実務(5), 理論計算実務(4), 載 貨集備(2), 船員労働(21)……労働の合理化(9), 労働の保全(9), 外国との比較(2), 船員学働運動史(1) 海難(17)……事例研究(6)，海難の諸原因の研究 $(6)$ ，海難の事後処理(4)，海難統計(1)，港運(12)……港 湾港運管理(3)，港湾港運関係者(3)，荷役合理化(2)，港運費用分析(2)，主要港湾事情(2)，運航管理 (6)……関係法規(3)，船長の権利義務(2), 船級(1),

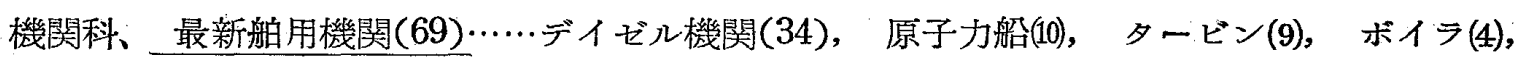


その他(12), 熱管理(16)……熱管理一般(10), ボイラ(6), 電気(59)….電気機器(38), 照明(5), 規格(4); 艤装(3), 新航海計器(5), 乙の他(4), 材料工作 (65) …材料(32), 各種工作(18), 溶接(10), 工作一般 (5), 潤滑(51)……潤滑油(44), 潤滑一般(7), 機関管理 (54)…․゙イーゼル機関(18)，ボイラ(10)，補 機(7)，タービン(3)，レシプロ(2)，その他(14)，海難(43)…‥事例研究(16)，応急注(9)，デイーゼル機 関(6), 海難統計(4), 事後処理(3), その他(3), ボイラ(2), 船員学衝(43)……学働力の保全(SD), 労働 ○合理化(9), 船員法(6), 賃金(6), 船内々拉け万人間関係(4), 外国船員学働(3), 戦後船員学働の特 質(2), 一般(2), 海運(31)……運航経済己機関部(11), 海運現状と展望(9), 海運経済一般(8), 海商法 (3), 計器 (30)……新計器(23), インデイケーター(4), その他(3),

\section{(2) 教科書の難易}

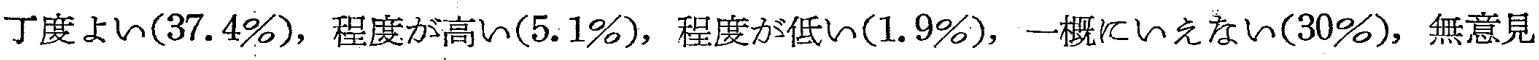
(4.6\%)，無記入 (21\%)，とい5結果となつたが、執筆者は部外者が多く、教科書全般にわたつ て釣合んのをれを水準を維持する上ら強い統制を行らてとはむづかしく、通信生の回答にしても 全部の教科書を通読してからの意見でなんと思われるから、一概にんえなんとん5のが真相に近 んのではなかららか。

(3) 教 材

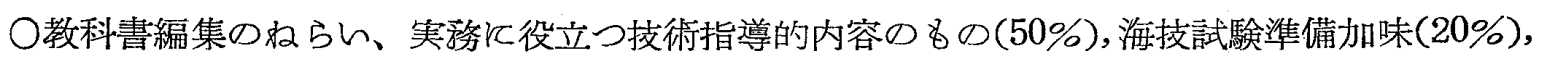
基璴理論(11\%)，新計器、機関、装備、海外文塥紹介(11\%)，一般教養(9\%)

○執筆者一の剂望、理論亡実際との総合をはかれ(33\%), 気軽と興味深く読めるものを(33\%). 実例を豊富につとめて図解式に $(33 \%)$

○編集方式、卧現状肯定的である。

○補助教标、充実をのぞさ。

(4) 教育指導 (数字は件数)

筫問制度を具体的にとりあげよ(18)，課題報告を具体的にとりあげよ(14)，スクーリングをとりあ げよ(13)，通信生の意見を教育実施ととりあげよ(6)

(5) 教 育 管 理

海上勤務の特殊性考考慮して、教育管理方式を改善せ上。関係者の理解をのぞむ。

\section{4 むすび}

1. 高等科通信教育発足当時の基本構想は、きわめて妥当なものであつたが、現在制度的に若 干の改善をなすべき時期に当面している。

2.との種の調查が今後をえ赦育実施の中に、有機的且つ継続的に織込すれなければ、通信 生のための通信教育の実現はむずかしん。

3. 教科書テーマと対する通信生の希望は船の現場で取組んでいる切実な問題あるいは切実な 問題の解決に寄与するよ5なものが多く、その職務に対する責任感の旺盛さには頭の下がる思い がする。まを通信教育のあり方につんての通信生の意見は妥当なものであると考えられる。通信 生の願望を確実につかみ、欲するとてろのものを与える民主主義精神てそ、ての教育に和んて最 も大切であろ5。即ち「通信生の、通信生による、通信生のための高等科通信教育」をできるだ け早く実現することが必要で、かくするとと放り本学院で担当している他の船員再教育のため に如をかな肥料が摄取できるであるら。

（4）高等科通信生は普通科通信生同様に船と共に海上を移動している゚関係者なかでも使用者 
側の協力がなければ、本教育の進展は期し得られなん。このため本教育につんての活発な広報活 動の必要性を痛感する。

（附图 1) 最终学歴别通信生数の变化

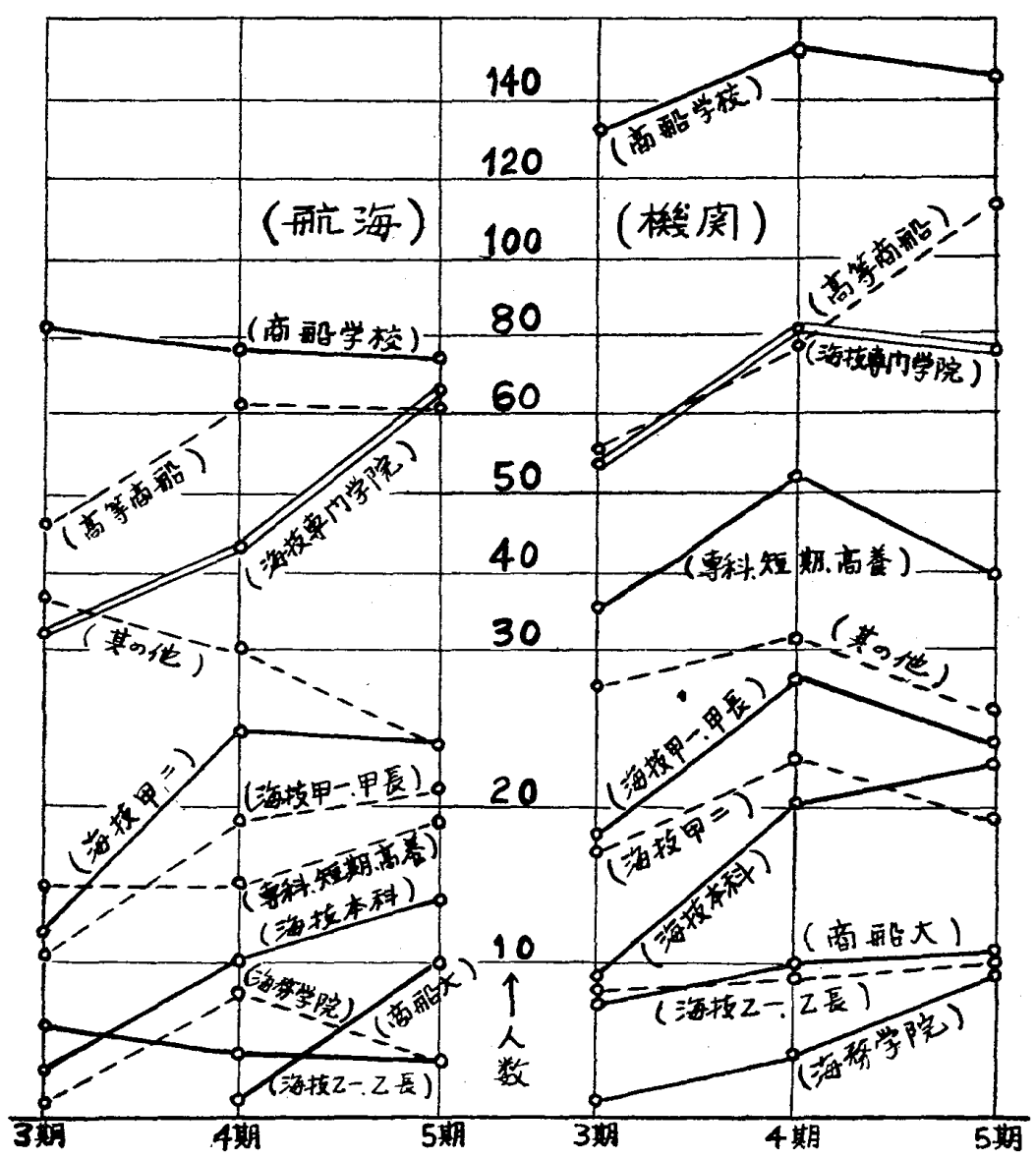




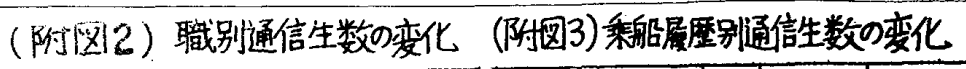
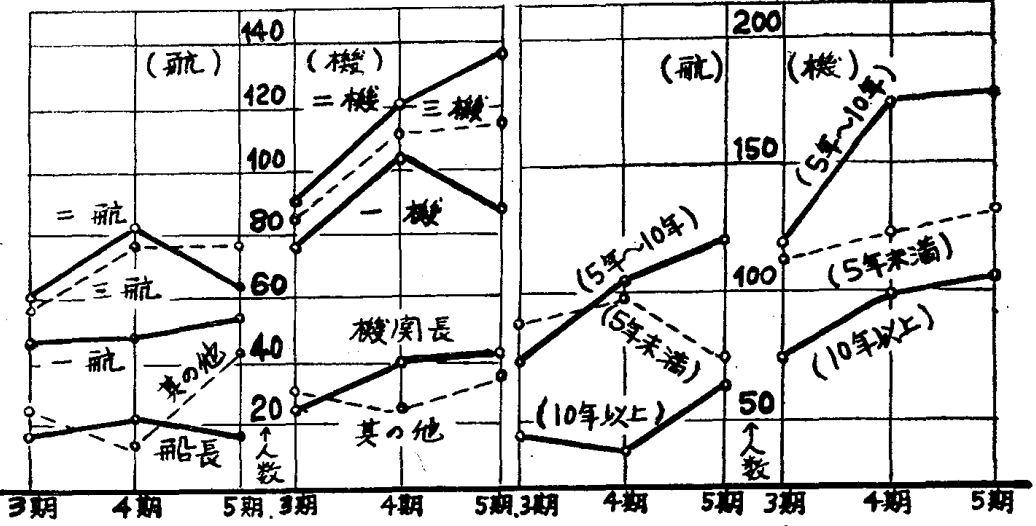

（附图4）所有海技免状别通信生数の变化

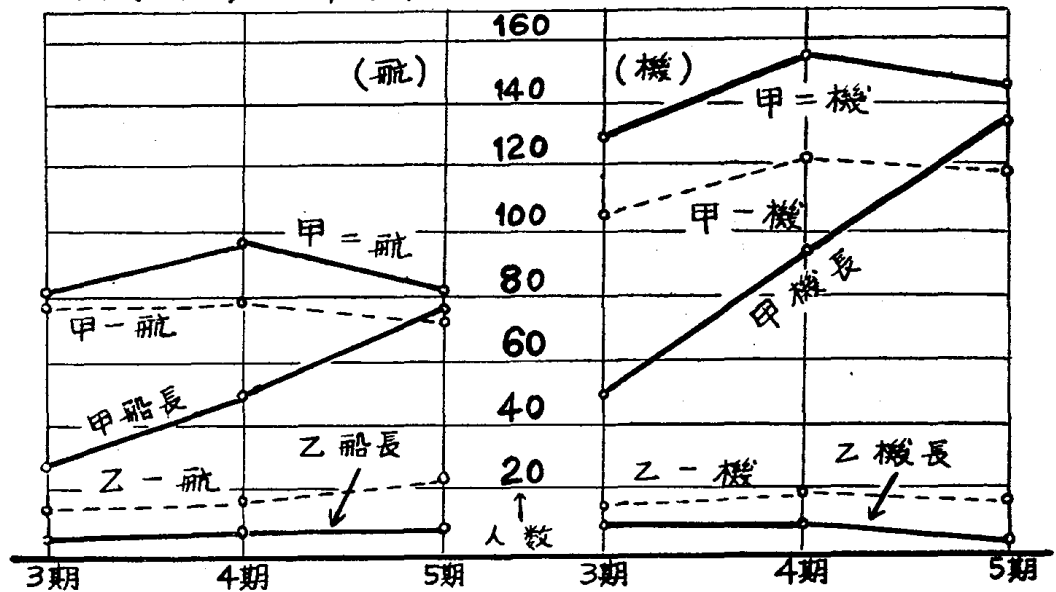

（附四５）高等科通信生の乘船履歴年数楧成

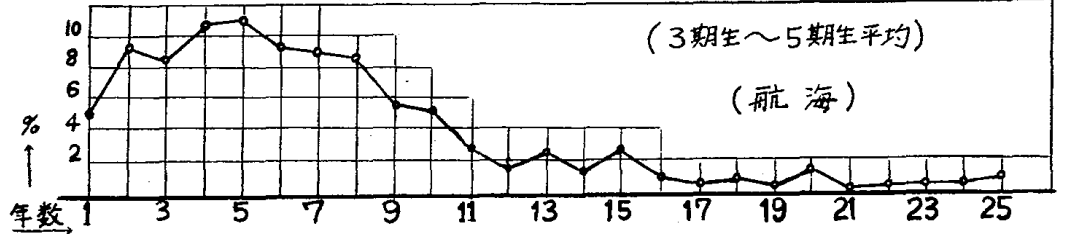

（附图6）高等科通信生の乘船履歴年数構成
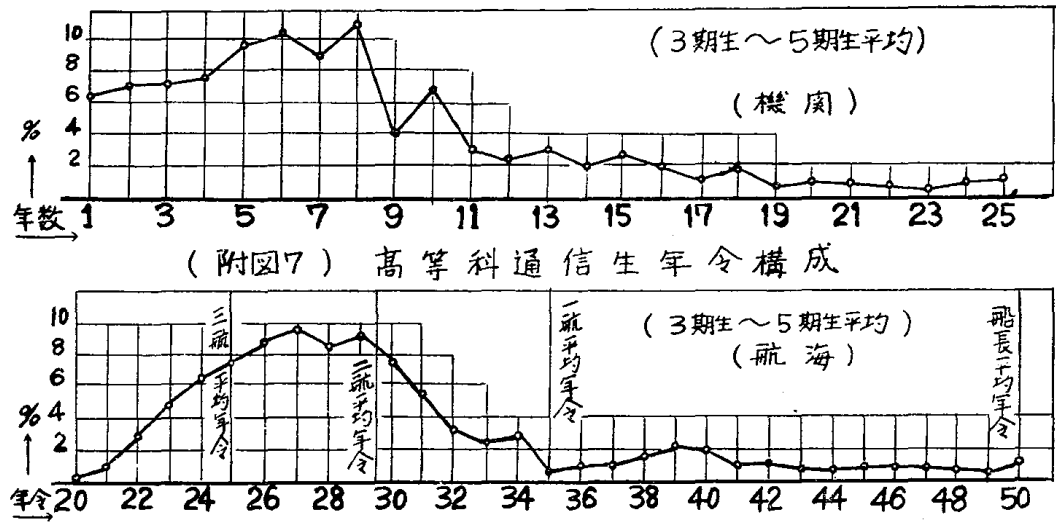

（附图8）高等科通信生年令棈成

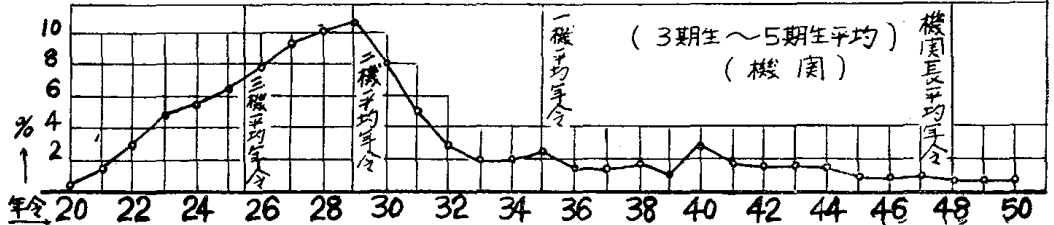


（附图 9）35才以下の高等科通信生の内訳

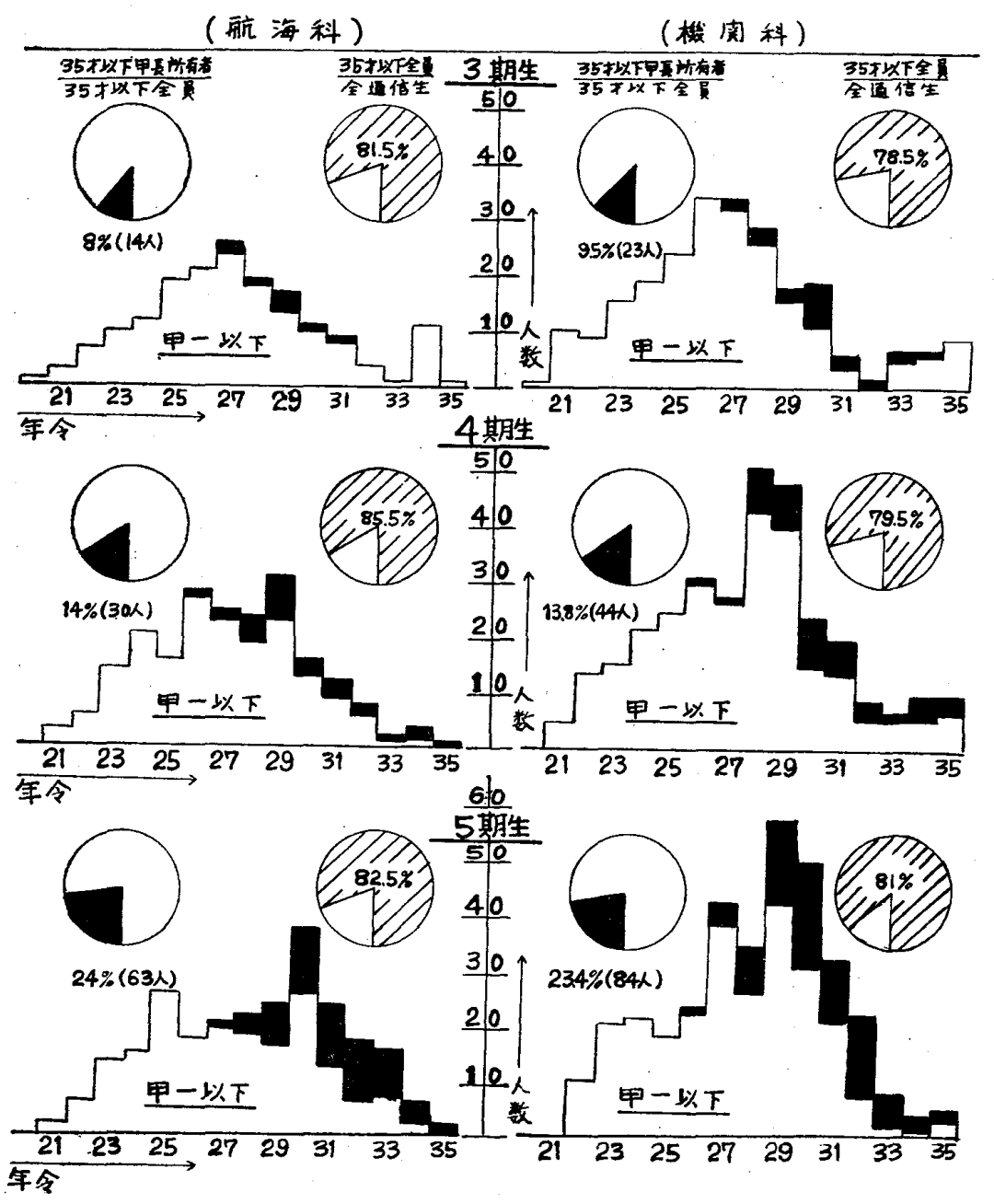




\section{（附图10）35才以下高等科通信生中の最高免状旂有者中学资 補助をしているX.Y社折属通信生の割合}
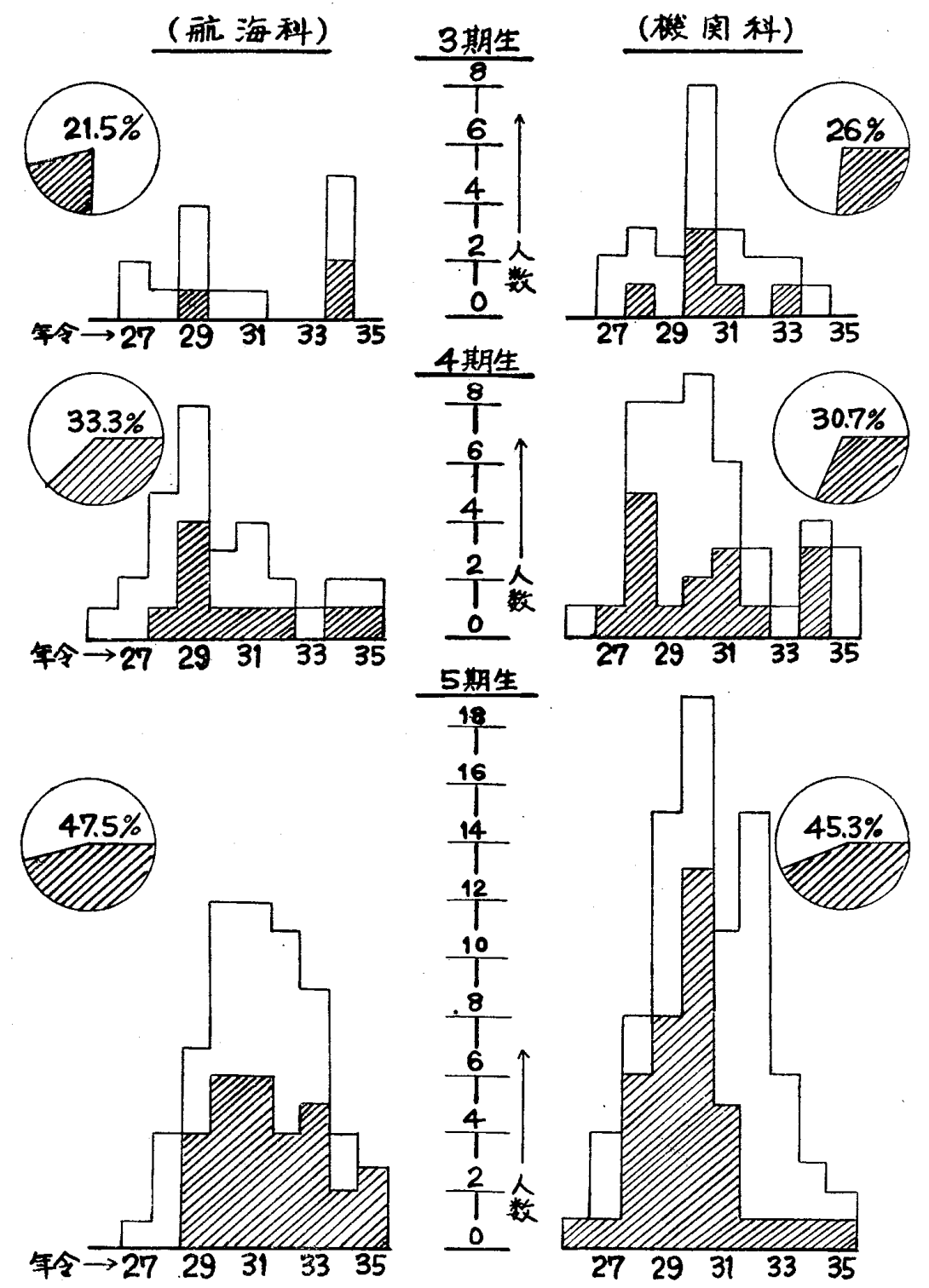
（附图11）高等科通信教育の普及度 甲機，職具80名以上の任意の10社の

$$
5 \text { 期生入学者 } \%
$$

$A$ B C D E F G H I J

社社社社社社社社社社

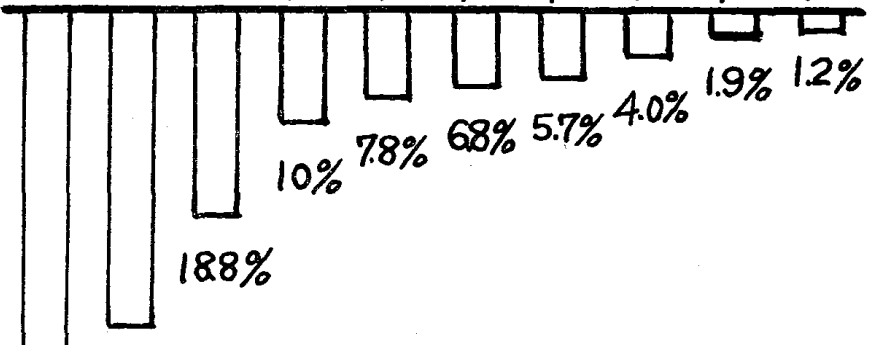

$29.8 \%$

(b)

$50 \%$

（附图12）各期别高等科通信生数

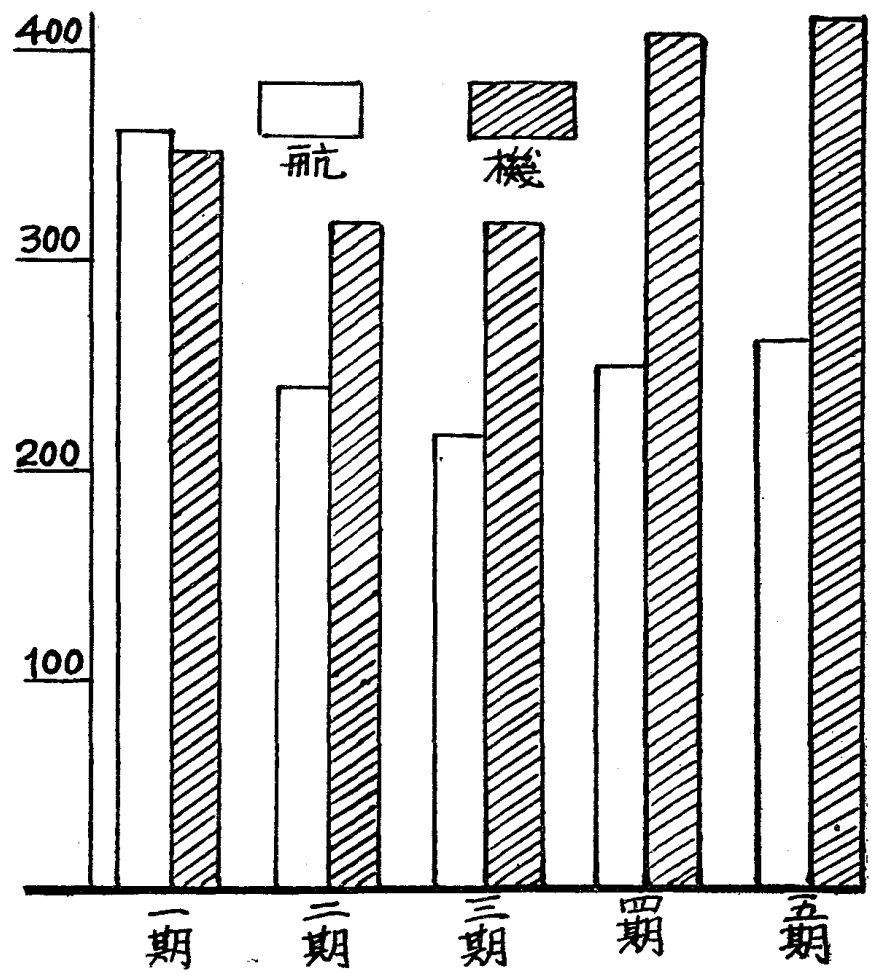

